\title{
Degree Standard System of Higher Education in China
}

\author{
Xinjian $Q u^{1}$, Fanqin Meng ${ }^{2, *}$ \\ ${ }^{1}$ Teaching Affairs Division, Dalian University of Technology, Panjin, China \\ ${ }^{2}$ Education Science College, Luoyang Normal University, Luoyang, China
}

\section{Email address:}

xinjianqu@dlut.edu.cn (Xinjian Qu), ssdsme@163.com (Fanqin Meng)

${ }^{*}$ Corresponding author

\section{To cite this article:}

Xinjian Qu, Fanqin Meng. Degree Standard System of Higher Education in China. Higher Education Research.

Vol. 5, No. 6, 2020, pp. 227-235. doi: 10.11648/j.her.20200506.14

Received: November 25, 2019; Accepted: April 17, 2020; Published: December 16, 2020

\begin{abstract}
The higher education degree standard is a social evaluation and academic norm for individual scholars pursuing academic achievements. It is believed that the prerequisite condition for establishing degree standard system is to acknowledge scientifically and rationally degree system. In this article, based on the analysis of the structural characteristics of degree system, we seek to deeply explore the degree awarding ways, degree standards and their interrelationships, and propose to start with the classification of talent training types and reconstruct the degree standard system framework in China's higher education with quantitative analysis methods. In order to clarify the framework of the degree standard system of China's higher education, we considered several elements, including the two dimensions of vertical degree level and horizontal degree type, and the relationship between these elements. In the vertical dimension, the degree standards from low to high are divided into three levels, such as the bachelor's degree standard, master's degree standard and doctoral degree standard. In the horizontal direction, there are three ways to cultivate talents through degree standards, namely degree standards, professional degree standards and honor degree standards. This research can be used as a development strategy and decision-making mechanism with a view to promote the transformation of China's higher education from scale expansion to connotative development.
\end{abstract}

Keywords: Degree System, Degree Awarding, Degree Standards, China's Higher Education

\section{Introduction}

The degree is widely recognized as an official quality certificate of education in today's era of neoliberal globalization [1]. This has led to the emergence of new cross-cultural and hybrid spaces [2, 3], and making transnational learning and academic immigration possible.

Degree standards are social evaluations and academic norms for higher education institutions to respond to individual scholars' pursuit of academic achievement. The right to award degrees is a highly prized and legally protected privilege [4]. Award degrees as a higher education strategic planning for improving the educational quality, which is an official document that determines policy direction, decision making and institutional strengthening within the university [5]. In China, the Standing Committee of National People's Congress has approved the Regulations of the People's Republic of China on Academic Degrees (RPRCAD) since 1980. And the State Council has approved the Provisional
Measures for Implementing the Regulations of the People's Republic of China on Academic Degrees (PMIRPRCAD) since 1981. The academic standards in PMIRPRCAD are regulated for three grades based on the degree system, such as Bachelor's Degree Standards (BDS), Master's Degree Standards (MDS) and Doctor's Degree Standards (DDS). The standardized and systematic management of degree standard system has strongly promoted the quality of China's higher education, such as informing students about their progression or informing institutions about their effectiveness [6]. According to the PMIRPRCAD, Bachelor's Degree should be conferred after the undergraduate learning, and Master's and Doctor's Degree should be conferred in the period of the graduate learning.

However, the degree standard system is a significant channel (or path) to improve the connotative development in Chinese higher education. It is believed that the prerequisite condition for establishing degree standard system is to acknowledge scientifically and rationally degree system. In 
this research, to expound the degree standard system framework in China's higher education, several elements were considered, included the two dimensions such as vertical degree levels and horizontal degree types, and the relationship between the elements. In the vertical dimension there are three levels from low to high of degree standards, such as bachelor's degree standards, master's degree standards and doctor's degree standards. In the horizontal dimension there are three types by the way of talents cultivation of degree standards, such as academic degree standards, professional degree standards and honorary degree standards. In this study, we should use quantitative analysis methods to deeply explore the degree awarding system, degree standards and their relationships, and proposes to start with the classification of talent cultivation types to reconstruct the framework of the degree standard system in China's higher education as a development strategy and decision-making mechanism. The purpose of the research is to promote the connotative development of higher education in China.

\section{Degree System of China's Higher Education}

\subsection{Degree System of China's Higher Education Constituting Analysis}

In the RPRCAD (1980), it was dictated that higher education would carry out degree system, including bachelor's degree, master's degree and doctorate degree three levels. The degrees' categories in China's higher education are divided into academic degree, professional degree and honorary degree three types. only one of which is honorary doctorate degree. As a result, China's higher education degree system framework in essence is a 3-3 matrix model (as figure 1), which is composed of three levels: (1) bachelor degree, (2) master degree, and (3) doctor degree; and of three types: (1) academic degree, (2) professional degree, and (3) honorary degree.

The academic degree is also called "science degree" in China's higher education. This is a type of degree division based on the nature and characteristics of the degree award requirements. Generally speaking, the requirements for academic degree awarding mainly focus on scientific theory and academic research, such as creative academic activities and higher-level scientific research capabilities, and master the subject and solid theoretical knowledge. The academic degree in the China's higher education system is equivalent to the philosophy degree in the European and American higher education system.

The professional degree is also called "vocational degree" in China's higher education. It is another type of degree that differs from academic degree. The main task of education for the professional degree in China's higher education is to meet the needs of social and economic development for specific occupations or positions. The goal of the professional degree education in Chinese higher education is to cultivate high-level applied talents who meet the actual work needs of these occupations or positions. The professional degree in China's higher education is equivalent to a graduate degree of British graduate education.

The honorary degree originated early in the UK. Honours degrees awarded by UK universities since the early 1980s has been widely noted in the context of an often polemical debate about standards [7]. Honours degrees awarded by China universities differ from UK in that only honorary doctorate degrees are awarded, except Bachelor of Honours and Master of Honours. The honorary doctorate degree is often officially approved by the Degree Committee of the State Council of the People 's Republic of China. The honorary doctorate degree is awarded in recognition of outstanding foreign scholars, scientists or well-known politicians and social activists in the fields of academia, economics, education, science, culture and health, recognize their contributions to social development and human progress outstanding contribution.

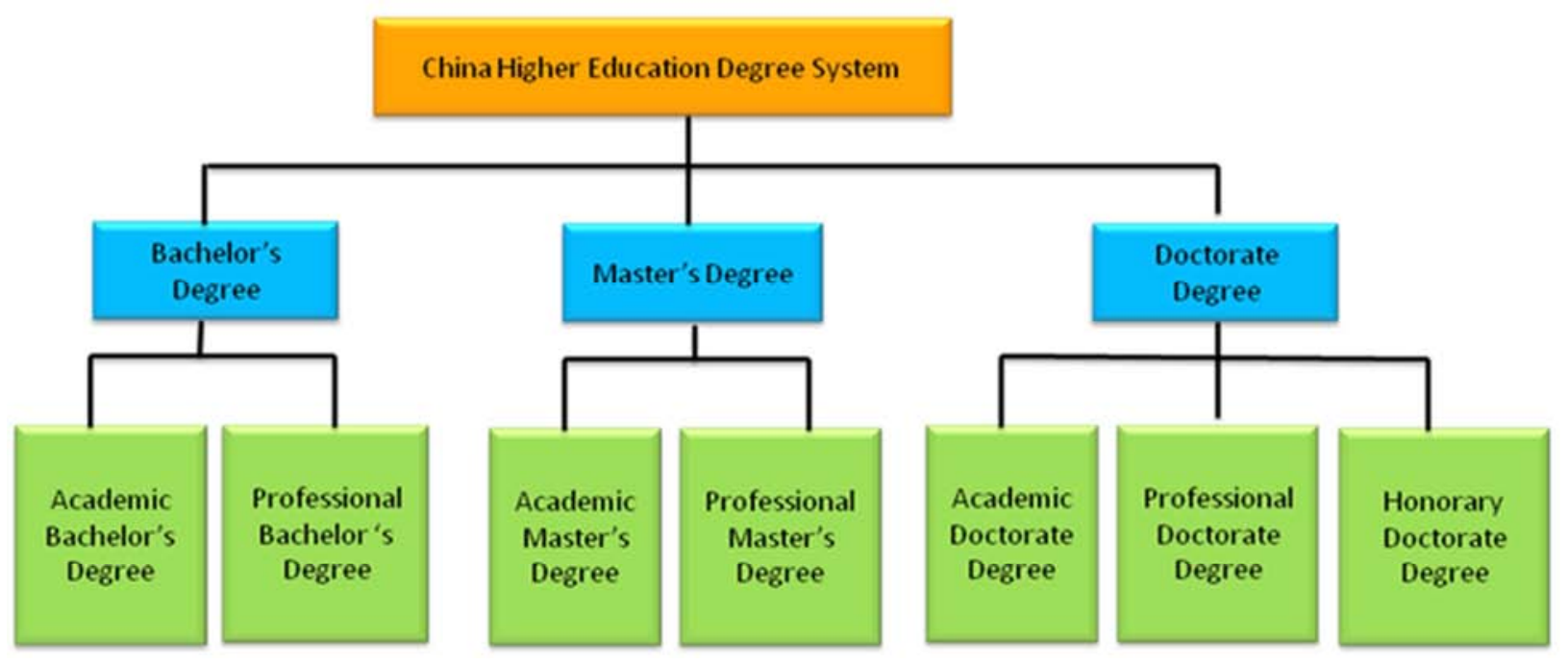

Figure 1. Degree System Framework in China's higher education. 


\subsection{Degree Awarding Ways and Quantitative Analysis}

\subsubsection{Academic Degree Awarding Ways and Quantitative Analysis}

The academic degree awarding ways mainly include two types: (1) according to vertical stratification, and (2) according to horizontal classification. In the vertical stratification dimension, the academic degree awarding ways include bachelor degree awarding, master degree awarding and doctoral degree awarding. In the dimension of horizontal classification, the degree awarding way in China's higher education is mainly based on subject categories (such as philosophy, economics, law, education, literature, history, science, engineering, agronomy, medicine, military science, management science and art), and up to 13 theme categories (Figure 2) [8]. By 2012, the total number of Chinese graduate students awarded degrees by subject category was 396,976 (see Table 1) [9], accounting for $71.61 \%$ of the total number of graduates $(486,455)$, and excluding students who have obtained honorary degrees. It should be noted that the way of awarding degrees by subject category is only applicable to academic degrees, and the way of awarding professional degrees is not.

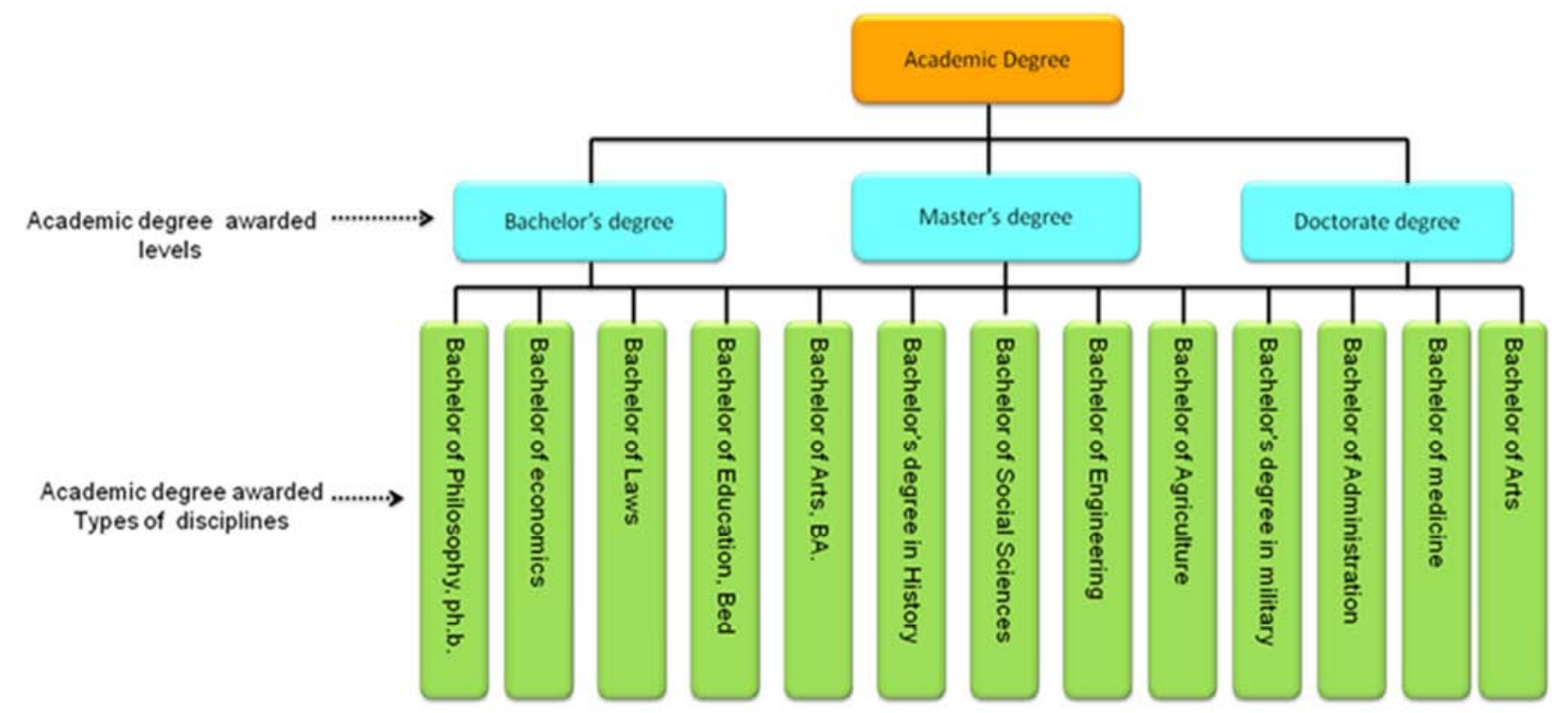

Figure 2. Academic degree awarding ways and types in China's higher education.

Table 1. Total Number of Postgraduate Students by Academic Field (2018).

\begin{tabular}{|c|c|c|c|c|c|c|c|c|c|c|c|c|}
\hline & \multicolumn{3}{|c|}{ Graduates } & \multicolumn{3}{|c|}{ Entrants } & \multicolumn{3}{|c|}{ Enrolment } & \multicolumn{3}{|c|}{$\begin{array}{l}\text { Estimated Graduates for } \\
\text { Next Year }\end{array}$} \\
\hline & Total & $\begin{array}{l}\text { Master's } \\
\text { Degree }\end{array}$ & $\begin{array}{l}\text { Doctor's } \\
\text { Degree }\end{array}$ & Total & $\begin{array}{l}\text { Master's } \\
\text { Degree }\end{array}$ & $\begin{array}{l}\text { Doctor's } \\
\text { Degree }\end{array}$ & Total & $\begin{array}{l}\text { Master's } \\
\text { Degree }\end{array}$ & $\begin{array}{l}\text { Doctor's } \\
\text { Degree }\end{array}$ & Total & $\begin{array}{l}\text { Master's } \\
\text { Degree }\end{array}$ & $\begin{array}{l}\text { Doctor's } \\
\text { Degree }\end{array}$ \\
\hline Total & 604368 & 60724 & 543644 & 857966 & 95502 & 762464 & 2731257 & 389518 & 2341739 & 818394 & 172824 & 645570 \\
\hline of Which: Female & 318985 & 23887 & 295098 & 459818 & 41012 & 418806 & 1355745 & 157255 & 1198490 & 409231 & 67034 & 342197 \\
\hline Academic Degree & 344155 & 58450 & 285705 & 411378 & 88718 & 322660 & 1319799 & 375344 & 944455 & 476857 & 168863 & 307994 \\
\hline Professional Degree & 260213 & 2274 & 257939 & 446588 & 6784 & 439804 & 1411458 & 14174 & 1397284 & 341537 & 3961 & 337576 \\
\hline Philosophy & 3883 & 677 & 3206 & 4292 & 925 & 3367 & 14750 & 4396 & 10354 & 5995 & 2245 & 3750 \\
\hline Economics & 29788 & 2142 & 27646 & 35493 & 3134 & 32359 & 94281 & 14789 & 79492 & 36877 & 7519 & 29358 \\
\hline Law & 40740 & 2933 & 37807 & 53159 & 4709 & 48450 & 158694 & 20121 & 138573 & 52332 & 10006 & 42326 \\
\hline Education & 35569 & 1063 & 34506 & 60281 & 1934 & 58347 & 190573 & 7750 & 182823 & 48285 & 3807 & 44478 \\
\hline Literature & 31833 & 1976 & 29857 & 37226 & 2867 & 34359 & 104552 & 12797 & 91755 & 40198 & 6561 & 33637 \\
\hline History & 5471 & 772 & 4699 & 6332 & 1143 & 5189 & 20279 & 5402 & 14877 & 7892 & 2798 & 5094 \\
\hline Science & 54621 & 12831 & 41790 & 73748 & 18894 & 54854 & 226291 & 73000 & 153291 & 76158 & 29010 & 47148 \\
\hline Agriculture & 22995 & 2762 & 20233 & 39003 & 4305 & 34698 & 125839 & 16560 & 109279 & 33710 & 7771 & 25939 \\
\hline Medicine & 70708 & 9699 & 61009 & 95172 & 14044 & 81128 & 271406 & 43162 & 228244 & 83815 & 15965 & 67850 \\
\hline Military Science & 159 & 23 & 136 & 89 & 9 & 80 & 446 & 122 & 324 & 259 & 96 & 163 \\
\hline Administrators & 79640 & 3227 & 76413 & 126968 & 4910 & 122058 & 395064 & 26155 & 368909 & 128872 & 14312 & 114560 \\
\hline Art & 19694 & 586 & 19108 & 27148 & 988 & 26160 & 77400 & 3440 & 73960 & 23847 & 1471 & 22376 \\
\hline
\end{tabular}

* Unit: person. 


\subsubsection{Professional Degree Awarding Ways and Quantitative Analysis}

Professional degree awarding ways also mainly include two styles: (1) according to vertical stratification, and (2) according to horizontal classification. In the dimension of vertical stratification, the professional degrees are also awarded by bachelor's degree, master's degree and doctorate three types.

In the dimension of horizontal classification, the degree awarding ways by major types mainly focus on the master's degree awarding in China's higher education. For example, professional master's degrees are awarded to engineering degrees, art degrees and education degrees, etc., a total of 39 types. In addition, professional doctorate degrees are only awarded to engineering degree, education degree, clinical medicine degree, veterinary degree and stomatology degree five types; while professional bachelor degree is only awarded to one kind of architectural professional degrees (as shown in Figure 3) [8]. However, driven by the needs of China 's social and economic development and the application-oriented shift of Chinese universities, the number of professional degree awarding issued by the Chinese government each year has shown a rapid growth, such as the number of national professional degree awards in the 1995-2009 academic year (see figure 4) [10]. By 2012, the total number of postgraduates with professional degrees in Chinese higher education had reached 89,479 (see Table 1 for details), accounting for $18.39 \%$ of the total number of graduates $(486,455)$ (among them, excluding students who awarded honorary degrees).

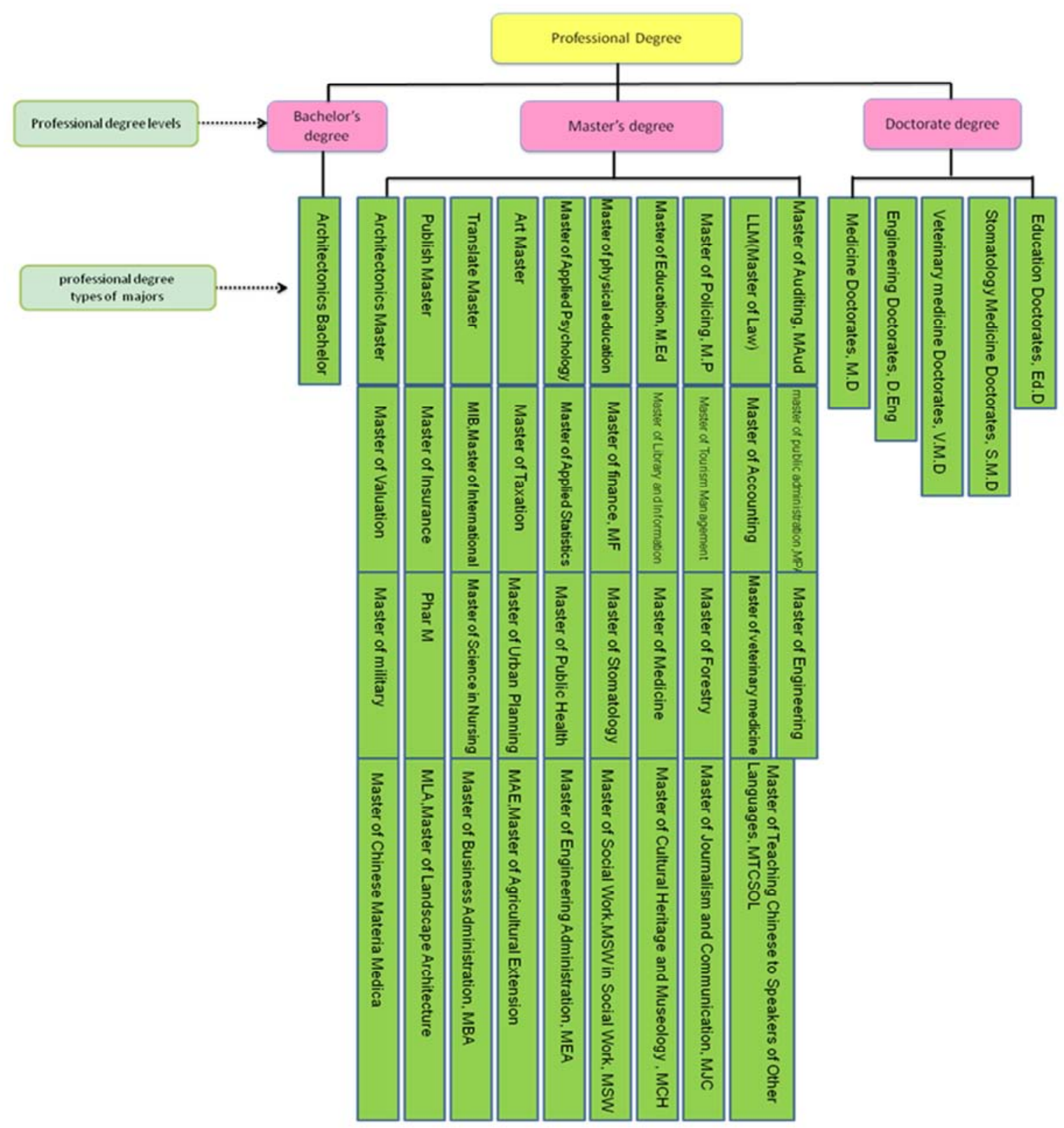

Figure 3. Professional degree awarding ways and types in China's higher education. 


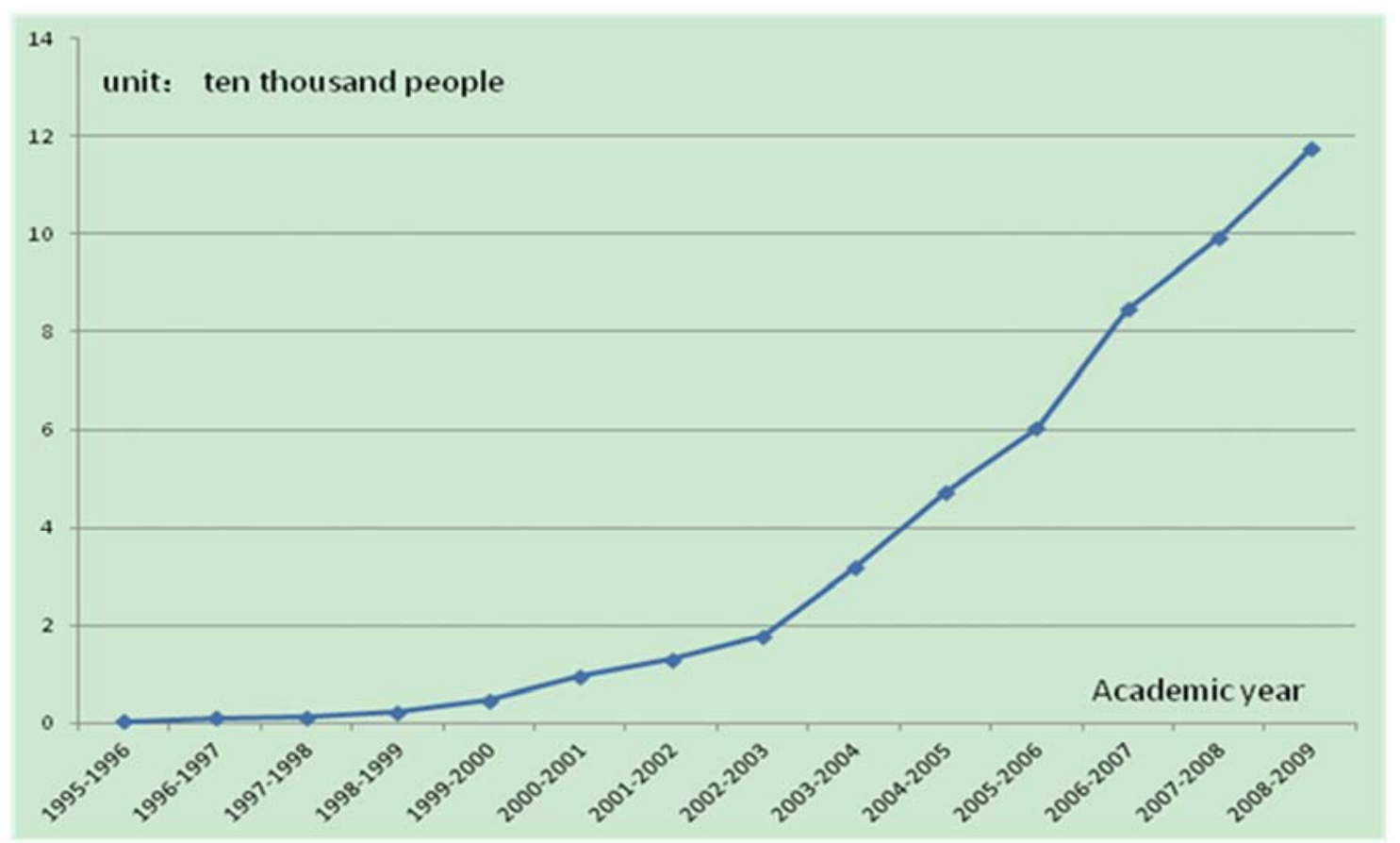

Figure 4. 1995-2009Academic Year National Professional Degree Grant Number.

\subsubsection{Honorary Doctoral Degree Awarding Quantitative Analysis}

In China, the honorary doctorate was first awarded in 1983. The honorary doctorate in China is awarded to recognize outstanding scholars, scientists or well-known politicians and social activists in the fields of academics, economics, education, science, culture and health, as well as social development and human progress in outstanding careers at home and abroad contribution. According to statistical analysis, by 2013, the total number of honorary doctorates in
China had reached 290 [11]. Among the total number, there are 28 scholars, 27 scientists, 20 social activists and 15 heads of government (including 13 heads of state), accounting for $31 \%$.

The study found that according to the year distribution of honorary doctorate degree awarding from 1983-2013 in China's higher education (see Figure 5), the number of honorary doctorate degrees awarded in 2009 was 23, by ranking first; and the number of honorary degree awarded in 2010 was 22 , by ranking second.

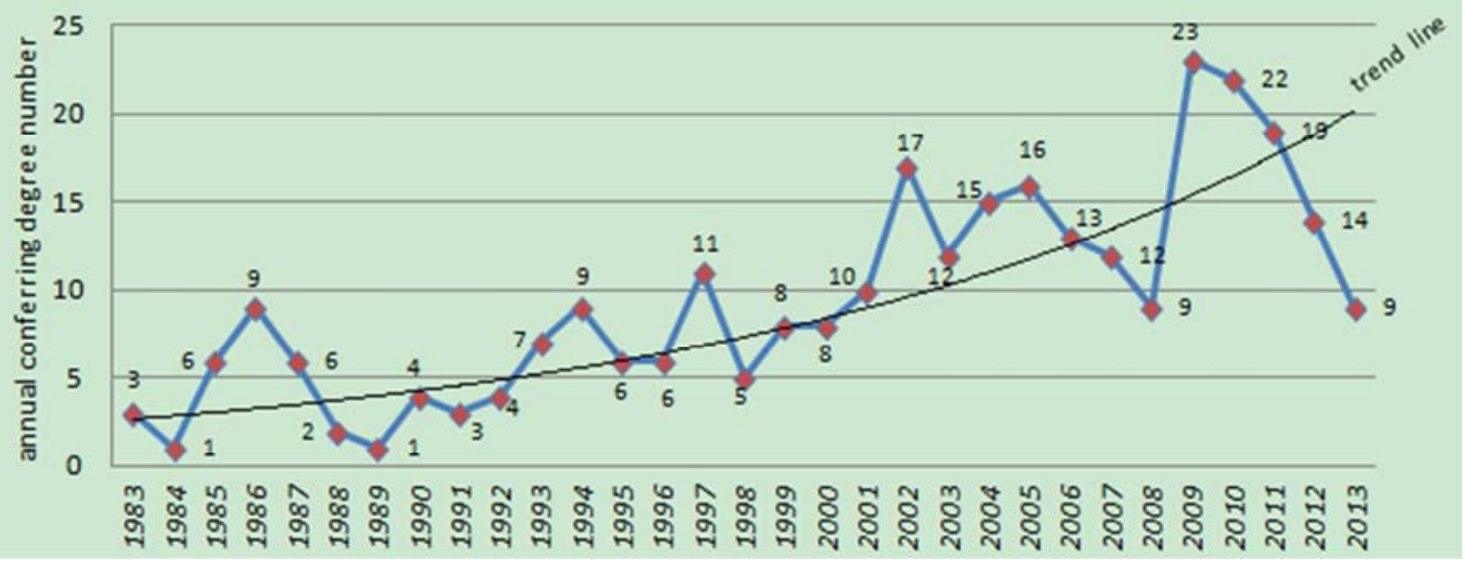

Figure 5. The year distribution of honorary doctoral degree awarding (1983-2013).

According to the statistical analysis of the nationality or region distributions of honorary doctorate degree awarding (1983-2013), the total number was 64 nationalities or regions by person-time greater than 2, as shown in Figure 6 for details. From 1983 to 2013, there were more than 2 countries and regions with the top 5 rankings including the United States (87 persons), Hong Kong (25 persons), Germany (24 persons), Japan (19 persons) and the United Kingdom (18 persons). And the number of honorary doctorate awarding by top five accounted for $59.66 \%$ of the total. 


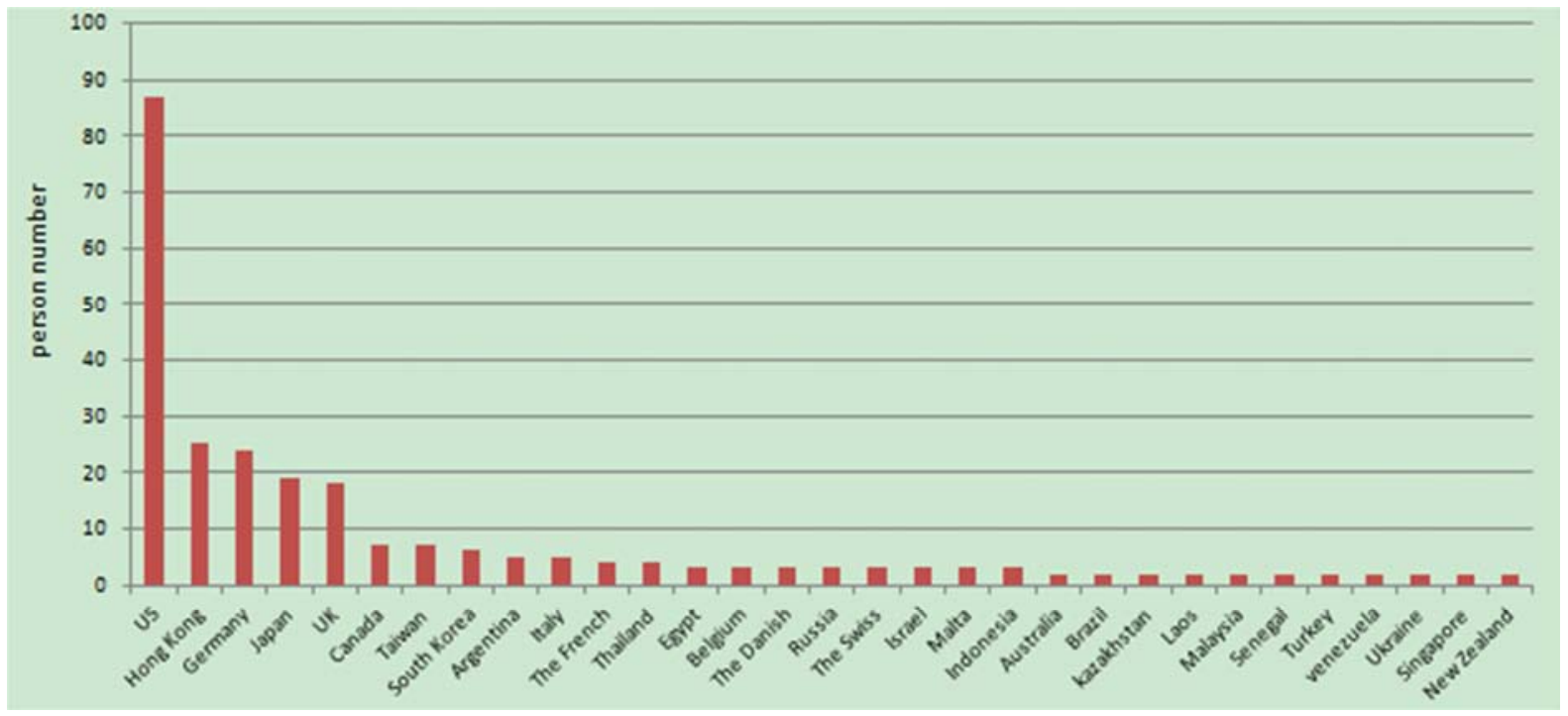

Figure 6. The nationality or region distributions of honorary doctorate degree awarding (1983-2013, person-time greater than 2).

According to quantitative analysis, the total number of conferring institutions for honorary doctoral degree from 1983 to 2013 was 67 universities (or educational institutions). The distribution of honorary doctorate-awarding institutions with more than 3 person-times is shown in Figure 7. In Figure 7, there are 7 universities with more than 10 honorary doctorate awards, such as Peking University (50 peron-times), Tsinghua University (20 person-times), Fudan University (15 person-times), Nanjing University (13 peron-times), Shanghai Jiaotong University (13 person-times), Renmin University of China (12 person-times) and Nankai University (10 person-times). The total number of honorary doctorate awarders in these universities (specifically refer to the 7 universities mentioned above) reached 133, and accounting for $45.86 \%$ of the total ( 290 in total).

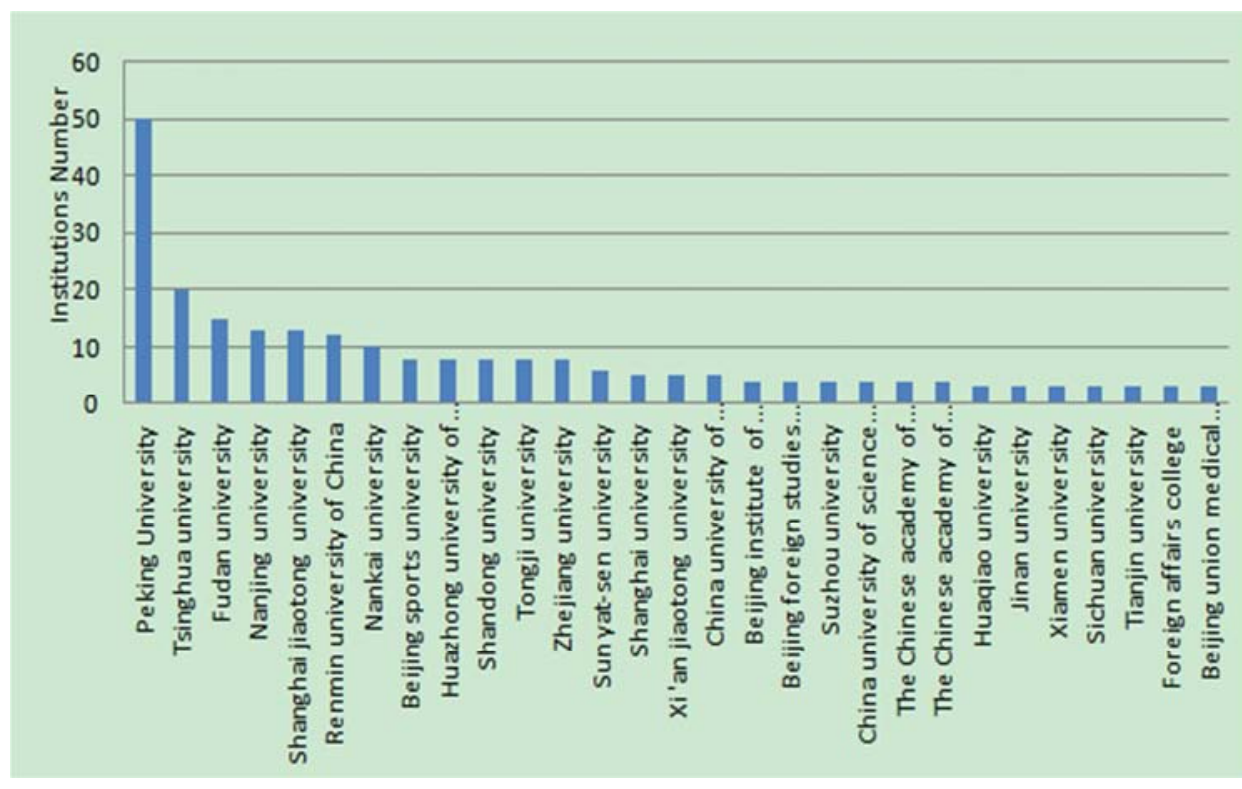

Figure 7. The number of conferring institutions for honorary doctoral degree (1983-2013).

\section{Degree Standards System Framework in China's Higher Education}

\subsection{The Interrelation Between Academic Degree Standards and Professional Degree Standards}

From the perspective of quality and standards, the relationship between degree standards and professional degree standards is not irreconcilable, but a coordinated relationship. For example, at the graduate level, the two can be converted to each other through a certain assessment mode. The specific relationship between degree standards and professional degree standards can refer to Figure 8 [1]. 


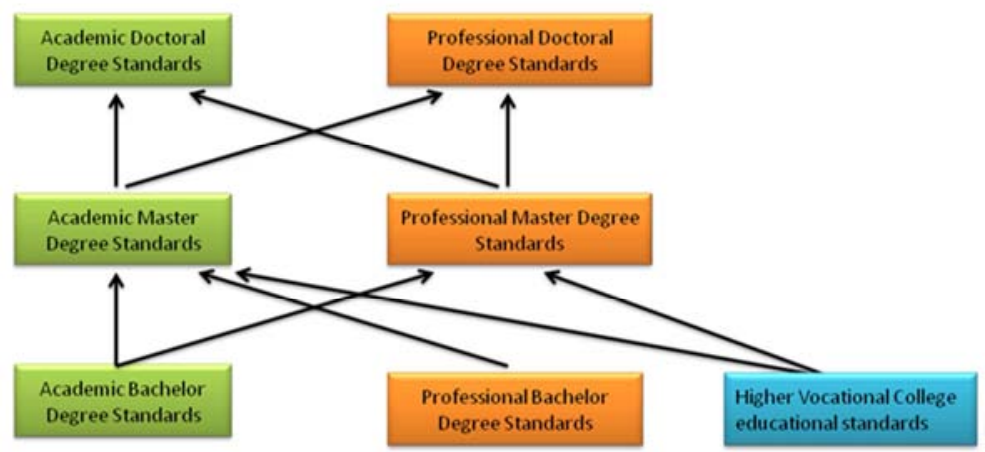

Figure 8. The interrelation between academic degree standards and professional degree standards.

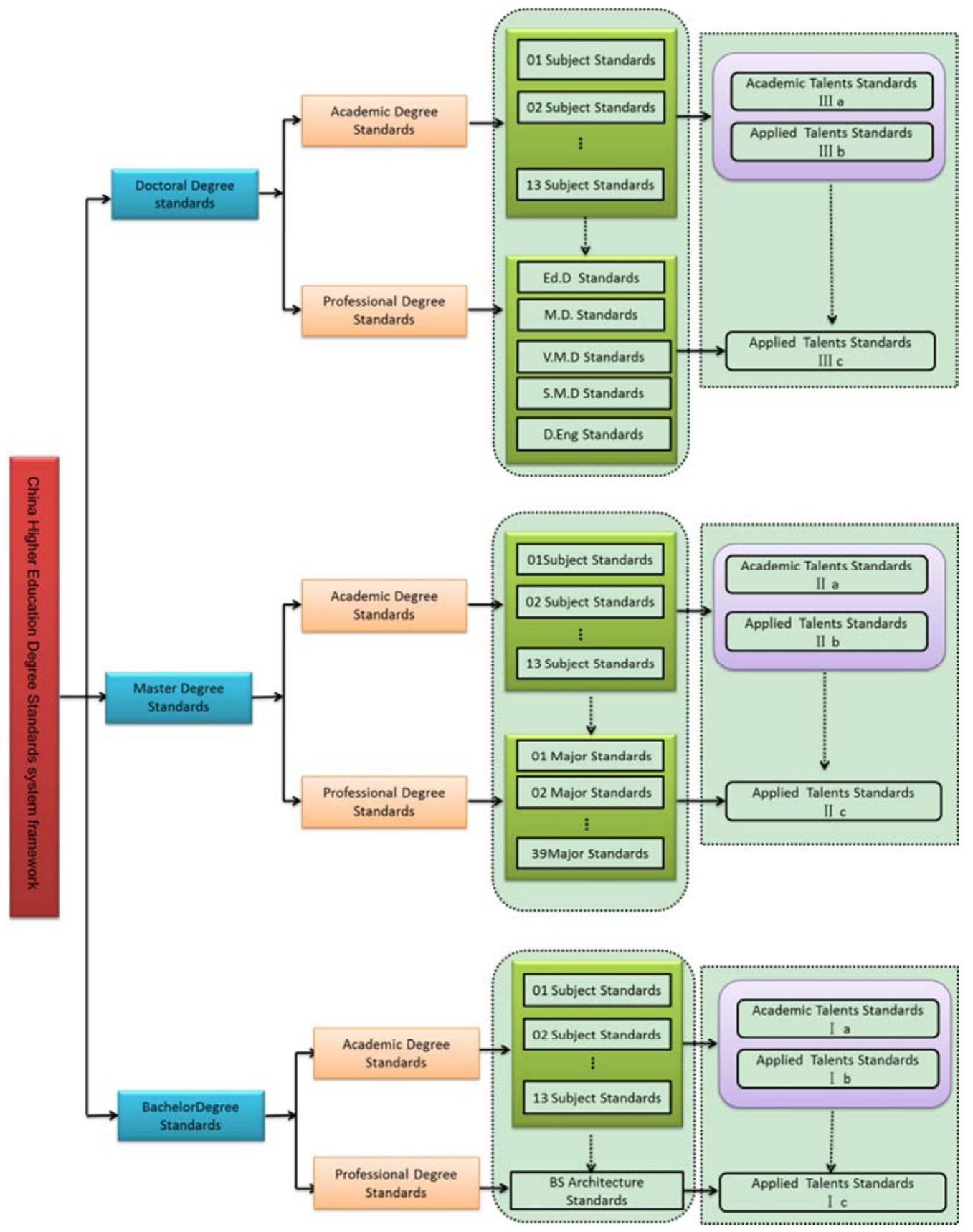

Figure 9. Degree standard system Framework of China's higher education. 


\subsection{Degree Standards System Framework}

As we all know, the essence of higher education is to cultivate senior talents. So, how to cultivate the senior talents? One opinion is that it entails selecting the best choice out of everything provided for students' learning. An eclectic is one who selects opinions from the purpose of the appropriate. In the field of education, the purpose is based on the value orientation from the employers for talents' types, such as academic talent or applied talent). At present, it mainly cultivates three kinds of talents in China's higher education, namely academic talents (a), academic-applied talents (b) and professional-applied talents (c). It should be noted that, for either (a) or (b), the degree after graduating is mainly awarded according to subject standards; and for (c), the degree is mainly awarded according to major standards after graduating. The major standard in Chinese higher education is equivalently programmes specification in European higher education. In the previous discussion, we have clarified that there are three levels in China's higher education degree system, namely bachelor's degree (I), master's degree (II) and doctorate degree (III). In principle, any degree-level of higher education can simultaneously cultivate three types of talents in the same period. In other words, a degree level includes three kinds of talents, such as I (a, b, c), II (a, b, c) and III (a, b, c).

In summary, the framework of degree standards system in China's higher education was shown as 3-9 mode. In the 3-9 model, the number 3 mainly means that it includes three levels (I, II, III), and the number 9 mainly means that it includes nine types of talents (Ia, Ib, Ic, IIa, II b, IIc, IIIa, IIIb, IIIc), as shown in Figure 9 for details.

\section{Conclusion}

In just 40 years (1980-2020), the degree management of higher education in China has achieved an institutionalized and standardized management model. In the process of degree system legislation in China, it is necessary to take into account both the traditional development of higher education and the realistic environment of academic evolution. In the era of higher education globalization, it has promoted the rapid improvement of the scale and quality of Chinese higher education.

As the saying goes, rapid changes have created new demands. In the new era, new industries look to higher education for help in the provision of new skills, specialized advanced training, consultancy and research support [13]. And considered deconstruction and reconstruction is the essence of critical transformation [14]. Therefore, with the development of modern society and economy, the degree standards and degree system framework of China's higher education should continue to be in a process of "constant change" [15-16].

The research is expected to provide employment or learning reference for the enterprises or employers, parents and students in China. In addition, the research also hopes to provide reference and guidance for some foreign students who are planning to choose to study in China.

\section{Acknowledgements}

This work is funded by the Philosophy and Social Sciences Planning Project of Henan Province with the project number 2018BJY019; by the Humanities and Social Sciences Research Project with the project number 2018-ZZJH-346; by Education Science Research Project of Luoyang Normal University with the project number 4015281 .

\section{References}

[1] Ploner, J., Nada, C. International student migration and the postcolonial heritage of European higher education: perspectives from Portugal and the UK. High Educ (2019). https://doi.org/10.1007/s10734-019-00485-2.

[2] Delanty, G. (2018). The European heritage: a critical re-interpretation. London: Routledge.

[3] Marschall, S. (2018), Ed., Memory, migration and travel. Abingdon \& New York: Routledge.

[4] Degree Awarding Powers Handbook for Applicants in England. QAA1726-Sept 2016. http://www.qaa.ac.uk.

[5] E J Usoh et al. Strategic Planning towards a World-Class University. 2018 IOP Conf. Series: Materials Science and $\begin{array}{llll}\text { Engineering } & 306 & (2018) & 012035\end{array}$ $10.1088 / 1757-899 X / 306 / 1 / 012035$.

[6] Fletcher, R. B., Meyer, L. H., Anderson, H., Johnston, P., \& Rees, M. (2012). Faculty and students conceptions of assessment in higher education. Higher Education, 64, 119133.

[7] Chapman, K. Degrees of difference: variability of degree results in UK universities. Higher Education 33, 137-153 (1997). https://doi.org/10.1023/A:1002974806122.

[8] China Academic Degree \& Graduate Education Information: Degree in Expo, degree types. http://www.cdgdc.edu.cn/xwyyjsjyxx/xwbl/xwzd/xwlx/. Accessed 20 October 2019.

[9] Number of Postgraduate Students by Academic Field (Total). http://www.moe.gov.cn/s78/A03/moe_560/jytjsj_2018/qg/201 908/t20190812_394203.html. Accessed 29 November 2019.

[10] China Academic Degrees \& Graduate Education Information: 1995-2009 Academic Year National Professional Degree Grant Number.

http://www.cdgdc.edu.cn/xwyyjsjyxx/gjj1/szfa/267338.shtml. Accessed 12 April 2018.

[11] http://baike.so.com/doc/4932962.html. Accessed 10 March 2019.

[12] http://www.cdgdc.edu.cn/xwyyjsjyxx/gjjl/szfa/267336.shtml. Accessed 20 December 2017.

[13] Shippey, Theodore Clive (1994). standards and quality in higher education $[\mathrm{M}]$. Cape Technikon Theses \& Dissertations. 
[14] Harvey, Lee; Knight, Peter T (1996). Transformation HigherEducation [M]. Societyfor Research into Higher Education, Ltd., London (England).

[15] Marope, P. T. M. Education: The key to development.
Prospects
47 ,
305-307
(2019).

[16] Coates, H. (2010). Defining and monitoring academic standards in Australian higher education. Higher Education Management and Policy, 22, 1-17. 